\title{
Geo-Political Patterns of Health Care Facilities in Kogi State, Nigeria
}

\author{
Oyekanmi Babatimehin ${ }^{*}$, Ayansina Ayanlade ${ }^{2}$, Muyiwa Babatimehin ${ }^{3}$ and Jubril Olu Yusuf ${ }^{4}$ \\ ${ }^{I}$ Department of Geography, Obafemi Awolowo University, Ile-Ife, Nigeria \\ ${ }^{2}$ Department of Geography, King's College, London \\ ${ }^{3}$ Human Resources Development Department, Nigerian Institute of Social and Economic Research (NISER), Ojoo, \\ Ibadan \\ ${ }^{4}$ African Centre for Development Research, Abuja
}

\begin{abstract}
This study is about the distribution of health care facilities in Kogi State within the context of the geography and politics of the state. Hence, the study analyses the spatial patterns of health care facilities among the three senatorial districts (which corresponds to the division along major ethnic lines) in the state. Also, the ownership structure of facilities and the relationship between population and distribution of health care facilities in the state are analysed. The list of health care facilities and ownership in Nigeria obtained from the Department of Health Planning and Research, Federal Ministry of Health served as database for the analysis of the spatial patterns of distribution and ownership of health care facilities in Kogi State. Also, the National Population Commission's census figures provided information on the population of the State. Kogi State was stratified into the three existing senatorial districts - Kogi Central, Kogi East, and Kogi West. The total number of health care facilities and their ownership in each stratum were determined and used for the analyses. Data show that there exist inequalities in the distribution of HCFs among the various senatorial districts in the state. Kogi east senatorial district recorded the highest concentration of HCFs having $66.3 \%$ of all HCFs in the state, followed by Kogi west (19.6\%) and Kogi central (14.1\%). It is observed that the facility-population ratios for both PHC and SHC (1:2575 and 1:29024 respectively) are high. These proportions vary among the various senatorial districts; for example PHC-population ratios were 1:6850, 1:2746 and 1:1689 for Kogi central, west and east respectively; the ratios for SHC were 1:41,859, 1:27804 and 1:23736 for Kogi central, west and east respectively. Although, the government dominates the ownership of health care facilities in the state, her impact is heaviest in Kogi east where she owns $93 \%$ of HCFs as opposed to $70 \%$ in Kogi central where the impact is least. Kogi east which has produced the civilian Chief Executives of the state since its creation in 1991 ranks far ahead of the two other districts in the distribution of HCFs. Appropriate authorities should endeavour to achieve a more equitable distribution of health care facilities in the state, so as to engender equity and social justice.
\end{abstract}

Keywords: Geo-politics, spatial patterns, health care facilities, Kogi State, Nigeria.

\section{INTRODUCTION AND RESEARCH PROBLEM}

Traditionally, Geographers have been interested in the spatial aspects of phenomena, which include the distribution questions, who gets what, and where. Geographical location is important in these matters because people live in places and thus location is one of the determinants of access to essential goods and services in geographic space [1]. Likewise of importance is the politics behind the locational decision.

In her study of health care delivery in Ibadan, Nigeria, Iyun [2] found, among other things, that hospitals were unevenly distributed both spatially and in the socioeconomic context. Okafor [1], went ahead to translate the distribution of hospitals into spatial pattern of accessibility. In as much as the locational aspect of facilities is important it is likewise imperative to consider the factors that have influenced the patterns of location. The concept of municipal

*Address correspondence to this author at the Department of Geography, Obafemi Awolowo University, Ile-Ife, Nigeria; Tel: +2348033728678;

E-mail: oyebabatimehin@yahoo.com politics $[1,3,4]$ is essential in understanding this relationship. Naturally, dichotomy exists between the rich and the poor, majority and minority groups, urban and rural localities. Discrimination may also exist by gender and socio-economic status. It is widely known even in highly organised societies that governments discriminate against the poor and minority groups in the provision of services. Government locational decisions and policies are generally in favour of those with power to influence the process.

This study among other interests situate the distribution of health care facilities in Kogi State within the context of the geography and political structure in the state. Hence, the study analyses the distribution of health care facilities among the three senatorial districts (which also corresponds to the division along major ethnic lines) and draws a relationship between population and distribution of health care facilities. This knowledge will further enhance our understanding of spatial patterns of facilities and the factors responsible for the observed patterns; and also, help in the effective distribution of facilities. 


\section{CONCEPTUAL FRAMEWORK}

\subsection{The Concept of Municipal Politics}

The concept of municipal politics reiterates that municipal governments discriminate against poor and minority groups in the provision of public services. Central to this is Lineberry's [3] underclass hypothesis, exemplified by Okafor [1]. It is widely believed that the re-distributive impacts of municipal locational decisions and public policy in general favour those with power to influence the process. In his study of western cities, Smith [4] remarked, that the rich and privileged have general allocative mechanisms working in their favour. In the same vein, Knox [5] observed that the ability of wealthy groups to manipulate bureaucratic machinery means that they are often able to attract a disproportionate share of public services. In essence, therefore, the locational outcome of municipal politics and public policy reflects the distribution of power in society.

Garrison [6] based on his analysis of the health sector in the US, opined that people, power, and politics are intrinsically linked in the matter of accessibility to health care. He observed that although great strides have been made in medicine, there are still millions of people who do not share in the gains. This he attributed to the imbalance in the operations of the three Ps - People, Power and Politics. He concluded that there is not a shortage of essential resources, but an inequitable distribution of health resources, and suggested a redistributive formula which should include entree for all minorities in the health industry at all levels.

Studies abound on the intra urban patterns of accessibility to health care facilities both in developed countries [7] and in Nigeria [1,8]. The general picture that has emerged is one in which poor people and poor neighbourhoods suffer some disadvantage. This phenomenon reinforces inequalities of the private market and defeats one of the primary objectives of public service provision which is the redistribution of real income in favour of less privileged groups. According to Okafor and Honey [9], the regressive patterns of health care provision in Nigeria and the consequent inequitable geographical access to health care services date from colonial times; and it is largely a result of the fact that the state no longer plays a neutral role because dominant or class interests tend to be favoured in the allocation and distribution of resources. The state reflects these power groups in deciding who gets what and where. Rural deprivation in Nigeria is a manifestation of this tendency. The constraint of rural spatial structure not withstanding, rural deprivation in the country is basically a function of the powerlessness of rural inhabitants. Otherwise, a situation in which more than 75 percent of all available major health manpower and facilities in the country is still concentrated in urban areas which account for about 30 percent of the country's population would be hard to rationalise [9].

\section{METHODOLOGY}

\subsection{The Study Area}

The study area, Kogi State which was created in 1991 is one of the thirty-six (36) states of the Federal Republic of Nigeria. Kogi State is located in the North Central part of Nigeria. The State lies between latitudes $7^{0} 30^{0} \mathrm{~N}$ and $8^{0} 10^{\prime}$
$\mathrm{N}$ and Longitudes $6^{\circ} 01^{\prime} \mathrm{E}$ and $7^{\circ} 50^{\prime} \mathrm{E}$, covering an area of about $27,747 \mathrm{~km}^{2}$. It shares common boundaries with Niger, Kwara, Nassarawa and The Federal Capital Territory to the north. In the East, the state is bounded by Benue and Enugu States; in the south by Enugu and Anambra States; and in the west by Ondo, Ekiti and Edo States. Lokoja, the Niger/Benue confluence town is the state capital. The 1991 Nigeria census puts the population of the state at 2,147,756 which spreads over 395,389 households. Politically, the state is divided into 3 senatorial districts - Kogi central, Kogi east and Kogi west. The state is further divided into 21 local government areas (LGA), with Kogi central, east and west having 5, 9 and 7 LGAs respectively (see Fig. 1).

The population of the state is mostly rural, as in most Nigerian rural communities, the economy of the area is largely agrarian. The sector employs a vast majority of the total workforce in the state. Farm labour is supplied mainly by families, hired labourers and work groups. In terms of infrastructural development, the area is still largely backward. Community effort towards development is very visible in the state.

Many rural communities in Kogi State still lack access to good health care facilities. Although, a number of primary health care centres dot the landscape, the poor services rendered at some of these centres call to question the rationale behind their establishment in the first place. Secondary and tertiary health care facilities are few in the state. Therefore, people have to travel several kilometres on bad roads in order to have access to good health care particularly secondary and tertiary care services. Besides the problem of inadequacy of health care facilities, the problem of bad roads and high cost of transportation makes accessibility to available health care facilities in the state and the referral services available outside the state highly difficult. Therefore, the issue of accessibility in rural areas goes beyond the straight-line measurement of people's location relative to the facilities in question. Other geographic and socio-economic factors must be taken into consideration.

\subsection{Data Type and Collection}

Data for this study were derived mainly from secondary sources. The list of health care facilities and ownership in Nigeria obtained from the Department of Health Planning and Research, Federal Ministry of Health (2000) served as database for the analyses of the spatial patterns and ownership of health care facilities in Kogi State. Also, the National Population Commission's 1991 National Census Summary provided information on the population of the various LGAs in the state. Kogi State was stratified into the three existing senatorial districts - Kogi Central, Kogi East, and Kogi West, with 5, 9 and 7 LGAs respectively. The total number of health care facilities and their ownership in each senatorial district were determined and used for the analysis.

\section{AN OVERVIEW OF THE PEOPLE AND POLITICS OF KOGI STATE}

\subsection{The People of Kogi State}

At inception in 1991, Kogi State had fifteen (15) LGAs which were distributed among the three senatorial districts as follows: Kogi west five (5), Central four (4) and East six (6). 


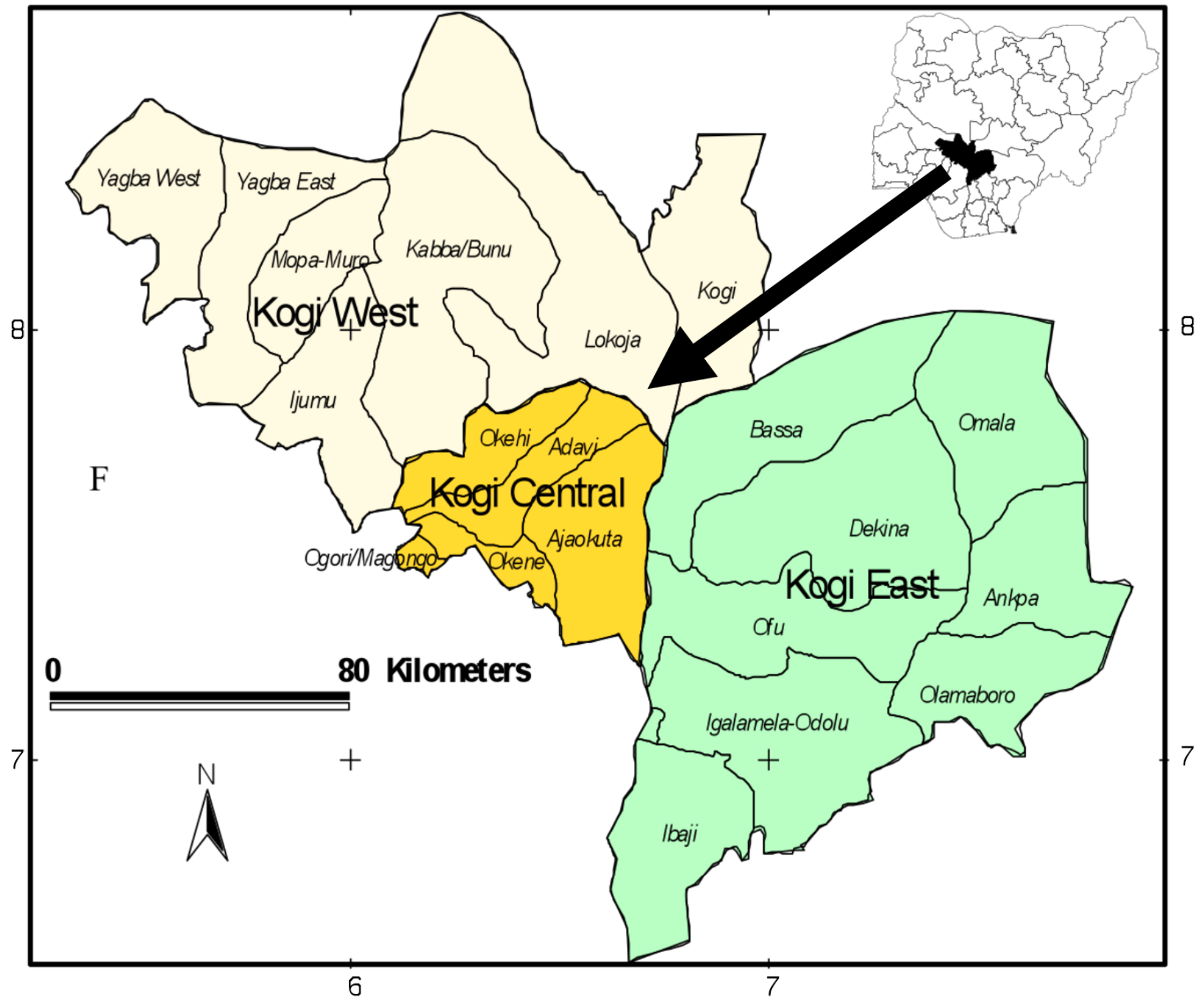

Fig. (1). Senatorial Districts and L.G.As in Kogi state.

In 1996, the number of LGAs was increased to the present 21 structure by the then military government. Kogi west has seven LGAs (Kabba/Bunu, Ijumu, Mopa-Amuro, Yagba East, Yagba West, Lokoja, and Kotonkarfi), Kogi central has five (Okene, Adavi, Okehi, Ajaokuta, and Ogori-Magongo in the Central) and Kogi east has nine (Ankpa, Omala, Dekina, Idah, Ofu, Olamoboro, Ibaji, Igalamela-Odolu and Bassa).

The state is a plural society. It has many ethnic groups, differing levels of social and economic development as well as many religions. The ethnic groups in the state include the Igbiras, Yorubas, Igalas, Bassanges, Nupes, Hausas, Bassankamos, Ogoris, and Gwagis. Three of these groups Igalas, Igbiras and Okun-Yorubas are in the majority. The Igalas inhabit the eastern part of the state, the Igbiras occupy the Kogi central, and the Okun-Yorubas occupy the western part of the state. The 2006 census puts the population of the state at 3,314,052. Christianity, Islam and traditional religions are the most prominent in the State. Social and economic development varies among the senatorial districts in the state.

\subsection{The Politics of Kogi State}

Discussing the politics of Kogi State is essentially trying to understand how the different groups that make up the state co-exist peacefully or otherwise. Each of the groups manipulate whatever means at its disposal (number, religion, ethnicity and power among others) to its advantage. Survival and development depend on the lever that each of the political units can pull to its own advantage. This is the context within which politics is played in the state. It is a question of which part of the state or from which ethnic group this or that political player comes; which part of the state or which ethnic group does a particular issue favours. Each of the three major ethnic groups in the state affirm what it terms its rights or interest, which it has sworn to protect and promote. While one is attempting to lord it over the other, the other resists. 
In a plural setting with pervasive poverty, like in Kogi State, the distribution of appointments and other patronages is very important. Power sharing to a very large extent determines the level of involvement or the lack of it in the running of the affairs of the state by each of the stakeholders. It helps to foster the sense of belonging, marginalisation or conquest, depending on what stakes each of the elements that make up the state hold. Sharing power through the allocation of public office (elective and appointment) is rationally expected to be based on the three Senatorial Districts. The principle to adopt is that of equity, in which case, each of the elements of the state should share out of the values of the state in a rational proportion worked out with all the stakeholders.

However, since the creation of the state in August 1991, all the Chief Executives (Governors) and some other key players in the state have come from the Kogi east senatorial district. Interestingly, those who have been running the affairs of the state (mostly from the eastern part of the state) seem to have applied a formula for the sharing of power in the state; which does not recognise the three Senatorial District structure, but rather Kogi East of the Niger and Kogi West of the Niger [10]. It is worthy of note that Kogi west of the Niger comprises two of the three Senatorial Districts, two of the three major ethnic groups in the state, as well as most of the minority ethnic groups. It also has a larger population figure $(1,834,908(55.4 \%))$ than Kogi East of the Niger $(1,479,144(44.6 \%))$. Most of the time, Kogi East, takes between $50-60 \%$ of whatever is to be shared and the rest are left for Kogi West of the Niger [10]. Interestingly, the political structure on ground in the state does not portend that the situation will change significantly in the near future.

\section{SPATIAL PATTERNS OF HEALTH CARE FACILITIES IN KOGI STATE}

\subsection{Category of Health Care Facilities and their Spatial Distribution in Kogi State}

Health care facilities in Nigeria are organised in a hierarchical system with three main components- primary, secondary and tertiary. Basically, the primary and secondary health care facilities dot the landscape in Kogi state. Available data show that there is no tertiary health institution in the state. Data from the Federal Ministry of Health show that there are 908 health care facilities in Kogi state, out of which $834(92 \%)$ are primary and $74(8 \%)$ secondary.

Kogi east senatorial district has the highest concentration of health care facilities. Out of the 908 health care facilities $602(66.3 \%)$ are located in Kogi east, 178 (19.6\%) in Kogi west and $128(14.1 \%)$ in Kogi central senatorial districts respectively. Specifically, there are 834 primary health care facilities in the state; out of which Kogi east senatorial district has $562(67 \%)$. Followed by Kogi west with 162 $(19.4 \%)$ and least in Kogi central with 110 (13.2\%). Therefore, it is not surprising to observe in Table $\mathbf{1}$ that the LGAs in Kogi east have the highest concentration of primary health care facilities. Dekina LGA has 115 (13.8\%), followed by Bassa $(83,10 \%)$ and Ofu $(73,9 \%)$ (all in Kogi east). The number of PHC facilities (271) in these 3 LGAs almost equals the number in Kogi central and Kogi west senatorial districts (272) put together. Whereas Kogi west is next in rank $(162,19.4 \%)$, Kogi central has the least number of primary health care facilities $(110,13.2 \%)$. OgoriMagongo (7), Mopa-Amuro (18) and Ajaokuta (21) LGAs respectively have the least number of PHC facilities in the state.

With respect to secondary health care facilities, again Kogi east senatorial district has the highest concentration in the state. Out of the $74 \mathrm{SHC}$ facilities in the state, Kogi east has 40 representing $54.1 \%$ of the state's total. Followed by Kogi central $(18,24.3 \%)$ and Kogi west (16, 21.6\%) respectively (see Table 1 and Fig. 2). However, the highest number of SHC facilities in any LGA is recorded in Okene (11, Kogi central) followed by Dekina (9), Bassa (8), Olamaboro (8), (Kogi East).

Table 1. Spatial Distribution of Health Care Facilities in Kogi State

\begin{tabular}{|c|c|c|c|c|}
\hline \multirow{2}{*}{ Senatorial District } & \multirow{2}{*}{ LGA } & \multicolumn{3}{|c|}{ Health Care Facilities } \\
\hline & & Primary & Secondary & Both \\
\hline \multirow[t]{7}{*}{ Kogi Central } & Okene & 36 & 11 & 47 \\
\hline & Adavi & 26 & 2 & 28 \\
\hline & Ajaokuta & 21 & 2 & 23 \\
\hline & Ogori-Magongo & 7 & 1 & 8 \\
\hline & Okehi & 20 & 2 & 22 \\
\hline & District Total & 110 & 18 & 128 \\
\hline & & $13.2 \%$ & $24.3 \%$ & $14.1 \%$ \\
\hline \multirow[t]{11}{*}{ Kogi East } & Ibaji & 39 & 3 & 42 \\
\hline & Idah & 43 & 1 & 44 \\
\hline & Igalamela & 70 & 3 & 73 \\
\hline & Ofu & 73 & 1 & 74 \\
\hline & Olamaboro & 70 & 8 & 78 \\
\hline & Ankpa & 40 & 6 & 46 \\
\hline & Omala & 29 & 1 & 30 \\
\hline & Dekina & 115 & 9 & 124 \\
\hline & Bassa & 83 & 8 & 91 \\
\hline & District Total & 562 & 40 & 602 \\
\hline & & $67.4 \%$ & $54.1 \%$ & $66.3 \%$ \\
\hline \multirow[t]{11}{*}{ Kogi West } & Yagba West & 20 & 2 & 22 \\
\hline & Yagba East & 32 & 2 & 34 \\
\hline & Kabba-Bunnu & 33 & 3 & 36 \\
\hline & Lokoja & 30 & 5 & 35 \\
\hline & Kogi & 29 & 1 & 30 \\
\hline & Mopa-Amuro & 18 & 3 & 21 \\
\hline & Ijumu & N.A & N.A & N.A \\
\hline & District Total & 162 & 16 & 178 \\
\hline & & $19.4 \%$ & $21.6 \%$ & $19.6 \%$ \\
\hline & State Total & 834 & 74 & 908 \\
\hline & & $92 \%$ & $8 \%$ & $100 \%$ \\
\hline
\end{tabular}

\subsection{Population and distribution of Health Care Facilities in Kogi State}

Access to health care facility entails much more than its availability. Indicators of accessibility include availability of health personnel, hospital equipments, and the ability to pay 


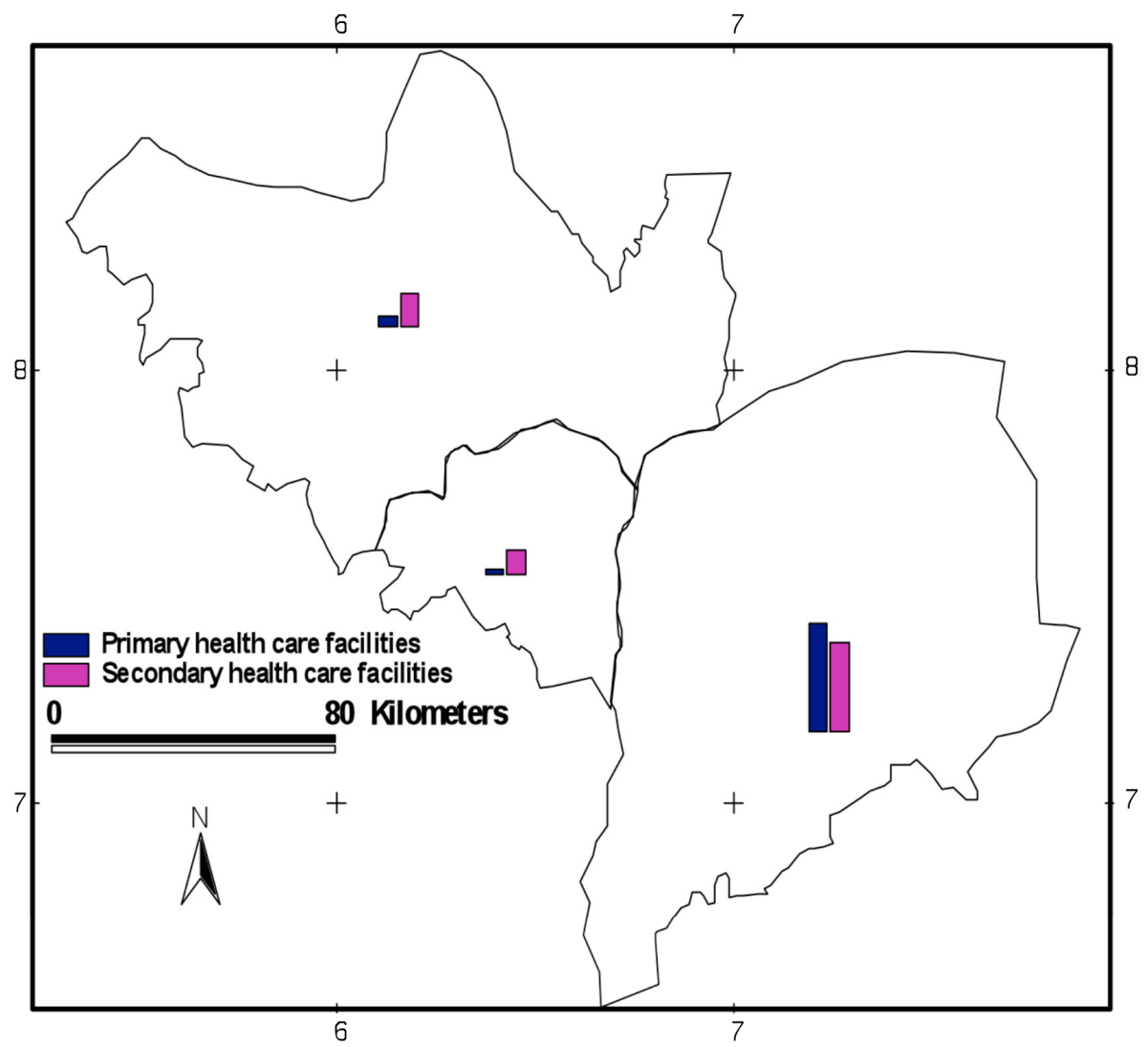

Fig. (2). Distribution of Health Care Facility in Kogi State.

among others. However, owing to the lack of data, this study has been limited to the analysis of spatial distribution of health care facilities. In spite of the limitations, this study will briefly discuss the ratio of the population to available health care facilities as an indicator of accessibility.

Generally, the ratio of population to available health care facilities in the state is least in Kogi east with a ratio of 1 health facility serving 1577 people. The ratio in Kogi west is 1: 2499 and 1:5886 in Kogi central. Specifically, the PHC population ratios are 1:1689, 1:2746 and 1:6850 for Kogi east, Kogi west and Kogi central respectively. For secondary health care facilities, the spatial pattern is not structurally different. The ratios are 1:23736, 1:27804 and 1:41859 respectively for Kogi east, Kogi west and Kogi central respectively (see Table 2). Table $\mathbf{2}$ show that Kogi east is within the average facility-population ratio for all the categories of health care facilities in the state. However, Kogi central could not meet the average for any category of the health care facilities and Kogi west is only able to meet the average for SHC facilities.

\subsection{Ownership of Health Care Facilities in Kogi State}

Basically, the ownership of health care facilities in the state falls into 3 main categories - government (state and local), religious organisations and the private. However, for the purpose of this study the facilities will be grouped into two categories - the public representing government-owned facilities (state and local governments); and private representing those owned by religious organisations, individuals or groups of people other than government.
Out of the 834 PHC facilities in the state, 762 are public, while 72 are private. In Kogi east senatorial district, there are 536 public $\mathrm{PHC}$ facilities as opposed to just 26 private. This gives a ratio of 1 private PHC facility to 21 public $\mathrm{PHC}$ facilities. In Kogi west, there are 146 and 16 public and private PHC facilities respectively. Giving a ratio of 1 private PHC facility to 9 public PHC facilities. In Kogi central, there are 80 and 30 public and private $\mathrm{PHC}$ facilities respectively. This gives a ratio of 1 private to 3 public $\mathrm{PHC}$ facilities. With respect to SHC facilities, again, government participation is heaviest in Kogi east, with government owning 23 SHC facilities. This is followed by Kogi west and Kogi central with 15 and 10 SHC facilities respectively (see Table 3). This implies that the advantage which Kogi east has over the other senatorial districts is not due to private participation but as a result of government support.

\section{SUMMARY AND CONCLUSIONS}

Kogi State is generally disadvantaged with respect to the availability of health care facility. Beside the non availability of THC facility in the state, facility population ratio for both PHC and SHC is too high for any acceptable standard. Within Kogi State, there is a noticeable spatial variation in the distribution of health care facilities among the various senatorial districts. It is observed that Kogi central is the most disadvantaged senatorial district. The senatorial district ranks far behind the two others in the distribution of all categories of health care facilities. On the other hand Kogi east ranks far ahead of the 2 other districts in the distribution of health care facilities. The senatorial district records $67.4 \%$ and $54.1 \%$ of the PHC and SHC facilities respectively. Even 
Table 2. Spatial Distribution of Population and Health Care Facilities in Kogi State

\begin{tabular}{|c|c|c|c|c|c|}
\hline \multirow{2}{*}{ Senatorial District } & \multirow{2}{*}{ LGA } & \multirow{2}{*}{ Population* } & \multicolumn{3}{|c|}{ No of Health Care Facilities** } \\
\hline & & & Primary & Secondary & Both \\
\hline \multirow[t]{6}{*}{ Kogi Central } & Okene & 317953 & 36 & 11 & 47 \\
\hline & Adavi & 157092 & 26 & 2 & 28 \\
\hline & Ajaokuta & 97904 & 21 & 2 & 23 \\
\hline & Ogori-Magongo & 34243 & 7 & 1 & 8 \\
\hline & Okehi & 146264 & 20 & 2 & 22 \\
\hline & $\begin{array}{l}\text { District Total } \\
\text { Facility-Population Ratio }\end{array}$ & 753456 & $\begin{array}{r}110 \\
1: 6850\end{array}$ & $\begin{array}{r}18 \\
1: 41859\end{array}$ & $\begin{array}{r}128 \\
1: 5886\end{array}$ \\
\hline \multirow[t]{11}{*}{ Kogi East } & Ibaji & 85239 & 39 & 3 & 42 \\
\hline & Idah & 55959 & 43 & 1 & 44 \\
\hline & Iga & 83494 & 70 & 3 & 73 \\
\hline & lamela & 108095 & 73 & 1 & 74 \\
\hline & Ofu & 104705 & 70 & 8 & 78 \\
\hline & Olamaboro & 185458 & 40 & 6 & 46 \\
\hline & Ankpa & 60476 & 29 & 1 & 30 \\
\hline & Omala & 177513 & 115 & 9 & 124 \\
\hline & Dekina & 88496 & 83 & 8 & 91 \\
\hline & Bassa & & & & \\
\hline & $\begin{array}{l}\text { District Total } \\
\text { Facility-Population Ratio }\end{array}$ & 949435 & $\begin{array}{r}562 \\
1: 1689\end{array}$ & $\begin{array}{r}40 \\
1: 23736\end{array}$ & $\begin{array}{r}602 \\
1: 1577\end{array}$ \\
\hline \multirow[t]{9}{*}{ Kogi West } & Yagba West & 76936 & 20 & 2 & 22 \\
\hline & Yagba East & 67864 & 32 & 2 & 34 \\
\hline & Kabba-Bunnu & 79584 & 33 & 3 & 36 \\
\hline & Lokoja & 82483 & 30 & 5 & 35 \\
\hline & Kogi & 50479 & 29 & 1 & 30 \\
\hline & Mopa-Amuro & 20916 & 18 & 3 & 21 \\
\hline & Ijumu & 66603 & N.A & N.A & N.A \\
\hline & $\begin{array}{l}\text { District Total } \\
\text { Facility-Population Ratio }\end{array}$ & 444865 & $\begin{array}{r}162 \\
1: 2746\end{array}$ & $\begin{array}{r}16 \\
1: 27804\end{array}$ & $\begin{array}{r}178 \\
1: 2499\end{array}$ \\
\hline & $\begin{array}{l}\text { State Total } \\
\text { Facility-Population Ratio }\end{array}$ & 2147756 & $\begin{array}{r}834 \\
1: 2575\end{array}$ & $\begin{array}{r}74 \\
1: 29024\end{array}$ & $\begin{array}{r}908 \\
1: 2365\end{array}$ \\
\hline
\end{tabular}

with respect to facility-population ratio, the senatorial district fares better than the two others. Whereas the facilitypopulation ratios in Kogi east are 1:1689 and 1:23736 respectively for PHC and SHC facilities; the ratios for Kogi central are 1:6850 and 1:41859 respectively. This extremely wide margin will be difficult to justify.

The assertion that the group that possesses power in the state use it to the advantage of its people cannot be better justified by the pattern of ownership of HCFs in the state. It is clear that the advantage of Kogi east senatorial district over the other two in the distribution of all categories of $\mathrm{HCF}$ is not as a result of private or community effort but rather massive government support. Kogi east which has produced the civilian Chief Executives of the state since its creation in 1991 ranks far ahead of the two other districts in the distribution of HCFs.

How do we rationalise a situation where over $2 / 3$ of public facilities in the state are allocated to a section of the state that has less than $50 \%$ of the population? A situation in which
Kogi east senatorial district, which has continued to dominate power in the state, uses the power to appropriate resources to itself does not engender peaceful co-existence and development in the state. The situation can create apathy towards government and governance on the part of the disadvantaged groups. It can lead to a state of chaos, where the disadvantaged groups want to take power at all cost or exhibit hostility towards the advantaged group which uses all arsenal at its disposal to stay put. Also, it can perpetrate corruption in the society because people can become nonchalant and have the tendency to grab whatever is within their reach.

Interestingly, the political structure on ground in the state does not portend that the situation will change significantly in the near future. Appropriate authorities and major players in the political scene should ensure a more equitable distribution of power and facilities in the state so as to engender equity, social justice, peaceful co-existence and development in the state. 
Table 3. Ownership of Health Care Facilities in Kogi State

\begin{tabular}{|c|c|c|c|c|c|c|}
\hline \multirow{3}{*}{ Senatorial District } & \multirow{3}{*}{ LGA } & \multicolumn{5}{|c|}{ Ownership of Health Care Facilities } \\
\hline & & \multicolumn{2}{|c|}{ Primary } & \multicolumn{2}{|c|}{ Secondary } & \multirow{2}{*}{ Both } \\
\hline & & Public & Private & Public & Private & \\
\hline \multirow[t]{6}{*}{ Kogi Central } & Okene & 23 & 13 & 4 & 7 & 47 \\
\hline & Adavi & 15 & 11 & 1 & 1 & 28 \\
\hline & Ajaokuta & 15 & 6 & 2 & 0 & 23 \\
\hline & Ogori-Magongo & 7 & - & 1 & - & 8 \\
\hline & Okehi & 20 & - & 2 & - & 22 \\
\hline & District Total & 80 & 30 & 10 & 8 & 128 \\
\hline \multirow[t]{10}{*}{ Kogi East } & Ibaji & 39 & - & 3 & - & 42 \\
\hline & Idah & 43 & - & 1 & - & 44 \\
\hline & Igalamela & 70 & - & 3 & - & 73 \\
\hline & Ofu & 73 & - & 1 & - & 74 \\
\hline & Olamaboro & 70 & - & 8 & - & 78 \\
\hline & Ankpa & 36 & 4 & 1 & 5 & 46 \\
\hline & Omala & 24 & 5 & 1 & - & 30 \\
\hline & Dekina & 100 & 15 & 4 & 5 & 124 \\
\hline & Bassa & 81 & 2 & 1 & 7 & 91 \\
\hline & District Total & 536 & 26 & 23 & 17 & 602 \\
\hline \multirow[t]{9}{*}{ Kogi West } & Yagba West & 15 & 5 & 1 & 1 & 22 \\
\hline & Yagba East & 21 & 11 & 2 & - & 34 \\
\hline & Kabba-Bunnu & 33 & - & 3 & - & 36 \\
\hline & Lokoja & 30 & - & 5 & - & 35 \\
\hline & Kogi & 29 & - & 1 & - & 30 \\
\hline & Mopa-Amuro & 18 & - & 3 & - & 21 \\
\hline & Ijumu & N.A & N.A & N.A & N.A & N.A \\
\hline & District Total & 146 & 16 & 15 & 1 & 178 \\
\hline & State Total & 762 & 72 & 48 & 26 & 908 \\
\hline
\end{tabular}

\section{REFERENCES}

[1] Okafor SI. Intra-urban patterns of accessibility to hospitals: a Nigerian case study: A research report funded by the Social Science Council of Nigeria (FORD II Project), 1990.

[2] Iyun BF. Spatial analysis of health care delivery system in Ibadan. Unpublished Ph.D. Thesis, Department of Geography, University of Ghana, Legon 1978.

[3] Lineberry R. Equality, public policy and public services: the underclass hypothesis and the limits to equality. Policy Politics 1976; 4: 67-84.

[4] Smith DM. Human geography: a welfare approach. Arnold: London 1977.

[5] Knox PL. The intraurban ecology of primary medical care: patterns of accessibility and their policy implications. Environ Plann 1978; A $10: 415-35$.
[6] Garrison DP. Three P'S of health care: people, power, politics. Ann N Y Acad Sci 1978; 310: 77-87.

[7] Knox PL. Medical deprivation, area deprivation and public policy. Soc Sci Med 1979; 13D: 111-21.

[8] Babatimehin O, Oyinloye RO, Nelson-Twakor EN, Taiwo OJ. Geo-spatial analysis of HIV/AIDS services and response sites in Benue State, Nigeria. Paper presented at the $51^{\text {st }}$ Annual Conference of the Association of Nigerian Geographers; 2011 February 14 - 19; Sokoto, Nigeria. Department of Geography, Usmanu Danfodiyo University 2011.

[9] Okafor SI, Honey R. Geographical perspective on the state and public service provision in Nigeria. Paper presented at the Staff/Graduate Students' Seminar, Department of Geography, University of Ibadan, Ibadan, Nigeria, 1993.

[10] Yusuf JO. The national question and the place of Okun people in Nigeria. African Centre for Development Research: Abuja 2006.

(C) Babatimehin et al.; Licensee Bentham Open.

This is an open access article licensed under the terms of the Creative Commons Attribution Non-Commercial License (http://creativecommons.org/licenses/by$\mathrm{nc} / 3.0 /$ ) which permits unrestricted, non-commercial use, distribution and reproduction in any medium, provided the work is properly cited. 